\title{
Whatsapp Voice Note for Teaching Speaking to the Seventh Graders in the Pandemic Era
}

\author{
Dwi Ide Rahayu \\ SMP Negeri 2 Adimulyo, Kebumen, Central Java \\ dwiiderahayu@gmail.com
}

\begin{abstract}
Some problems occur in the teaching and learning speaking to the seventh graders in the pandemic era in Indonesia. The first cause is the fact that for the seventh graders, it is their first experience in learning English formally at school since they have not learned English when they were in the elementary school. Then, the students do not have sufficient internet quota and signal. Moreover, the students also have not been digital literate yet in operating the Learning Management System. One of the solutions offered is by using the online media which is most familiarized by students, such as Whatsapp Voice Note. This study is aimed to find out (1) the students' perception on the use of Whatsapp Voice Note in teaching and learning speaking to the seventh graders and (2) can Whasapp Voice Note improve students' participation in the teaching and learning process. The descriptive qualitative is applied as the method of this study. The instruments are survey, interviews, and observation. The result shows that (1) the seventh graders students prefer to be taught the speaking skill by means of Whatsapp Voice Note and (2) by using Whatsapp Voice Note, most of the students are able and eager to participate more in the teaching and learning process.
\end{abstract}

Keywords: Teaching Speaking, Pandemic Era, Whatsapp Voice Note, Seventh Grade Students

\section{Introduction}

In the curriculum applied in Indonesia, English is taught to the students of Junior High School (the seventh graders) until to that of the students of university level. As a result, for the seventh grade students, it is their first experience to learn English in a formal situation. One of the basic competences in the recent Indonesian curriculum is that students are hoped to be able to compose written and spoken transactional interaction texts. In other words, speaking skills become one of the skills that have to be mastered by the students.

The teaching of speaking to the seventh grade students in Indonesia is not an easy job since English is taught as a foreign language. One of the characteristics of teaching English as a Foreign Language (TEFL) is the lack of exposures of the target language. Moreover, the students can only meet a rare opportunity to use English as a means of communication in their daily life (Brown, 2000: 116). The challenge has been bigger in the pandemic era when the teacher are not able to teach the students directly or face-to-face.

There are six types of the teaching and learning of English speaking in the class (Brown, 2000: 271-274). Some of the types that are taught to the seventh grade students based on the curriculum implemented recently in Indonesia are the skills to (1) imitate, which goal is to make the students to be able to imitate small part of language form; (2) responsive, which goal is to make the students to be able to answer simple questions; (3) transactional, which goal is to make the students to be able to exchange certain information; and (4) interpersonal, which goal is to 
make the students to be able to make social relationship in the society. The English speaking skills is considered to be difficult to master, since it needs the ability to use it directly in the daily interaction. Because of that, the English teachers play a very important role.

The roles of the teachers in the teaching and learning of speaking are as a prompter, a participant, and a feedback provider (Harmer, 2007: 347-348). As a prompter, a teacher has to be capable of assisting the students in producing spoken language. A teacher, as a participant, has to be able to be a good stimulus for students to produce spoken language. Then, a teacher as a feedback provider means that a teacher's duty is to respond to the content of the teaching and learning of speaking activities as well as the accuracy of the spoken language used. In addition, a teacher must make sure that students really understand what they should do. So the teachers' instruction has to be clear.

Most of the teaching and learning processes in the pandemic era are conducted by means of Learning Management System (LMS). However, in the school where this study is carried out, the teaching and learning through LMS does not effective. It is shown by the chilly atmosphere of the teaching and learning process and the low participation of the students. Some of the reasons are (1) the students are not digitally literate enough to perform the LMS which they never use before and (2) the students does not have sufficient internet quota or signal to access the LMS. Thus, a teacher should use another option to teach, for instance by using the most familiar and the easiest learning media such as Whatsapp Voice Note.

Whatsapp can be described as a means to interact with friends and/or teachers about certain topics (Najafi and Tridane, 2015). It is applied mostly because it is economical and well known of the students (Kusuma and Hamidah, 2020). It is also one of the media which is most preferred by students (Zhafira, 2020). The Whatsapp voice note allows the users to chat or share information faster since the users do not have to type anything. In relation to teaching speaking, this feature can be used by teacher to give a model in pronunciation, to assess students' speaking skills directly, and to give feedback. It is in line with the roles of the teacher in teaching speaking. Harmer (2007: 347-348) states the roles of teachers in teaching speaking are as a prompter, as a participant, and as a feedback source.

Meanwhile, for students, the Whatsapp Voice Note allows students to confidently express themselves by using English orally (Mistar, 2016). Some of previous studies reveal that the use of Whatsapp voice note is effective in mobile learning especially for teaching speaking and in improving students' participation (Amry, 2014; Gon and Rawekar, 2017; Ayuningtyas, 2018; Riyadoh, 2018; Nurazizah, Frihatin, and Sugiarto, 2019; Yulianto, Cahyani, and Silvianita, 2020). However, those studies are conducted in senior high school and university level. There is only atypical study conducted in the junior high school level. Thus, this study will only investigate the use of Whatsapp voice note in teaching speaking to the seventh graders students in the pandemic era. Therefore, the questions of the study are as follows.

(1) How are the students' perception of the use of Whatsapp voice note in teaching and learning speaking in the pandemic era?

(2) Can Whatsapp voice note improve students' participation in the teaching and learning speaking processes in the pandemic era?

\section{Research Methodology}

\subsection{Research Design}

This study is designed as a qualitative case study. Thus, this study makes use of the natural background. It does not employ the statistical analysis procedures. It is a descriptive one. 
Therefore, this study is based on findings which are examined in detail, formed with words, holistic and complex pictures. The data is collected by means of observation, survey, and indepth interviews. From the result of the observation, the data of students' participation in the teaching and learning process can be collected. Survey and in-depth interviews are utilized to gain the data on students' perception in using Whatsapp Voice Note in teaching speaking.

\subsection{Participants}

This study is conducted in two classes of grade seven in SMP Negeri 2 Adimulyo, Kebumen, Central Java. The number of students participating in this study is 64 students. These classes are chosen since the students of these two classes face problems in the teaching and learning English, especially the speaking skills. Their participation in the class is low.

\subsection{Technique of Data Collection}

The study is accomplished by use of observation on the process of teaching and learning of speaking. From the result of the observation, the data of students' participation in the teaching and learning process can be collected. It can be known whether the students are more eagerly active in participating in the class or not. Surveys are done in order to get the data of students' perception on the use of Whatsapp Voice Note in teaching and learning of speaking. Then, to gain deeper understanding on the data, in-depth interviews are employed.

\subsection{Technique of Data Analysis}

This study is designed as a qualitative case study so that the data collection and analysis can be strength since it consents to a theory development which is grounded in empirical facts (Hartley, 2004: 329). Moreover, a vigilant data description and the development of categories in which to place behaviors or process have proven to be important steps in the process of analyzing the data. The data then be organized around the study's central questions, and finally the data are scrutinized to find out how far they fit or fail to fit the expected categories. Finally, the checking of the findings with the case study participants is conducted. It can be a valuable part of the analysis and can enhance validity (Hartley, 2004: 330). The analyzing of the data is improved by reference to the existing literature and making use of this to raise questions about whether the researcher's findings are consistent with or different from previous existing studies.

\section{Findings and Discussions}

Before the Whatsapp Voice Note is used, the circumstances of the teaching and learning of speaking in the two classes are as follows. First, the students' participation is low. Only a few students who submit assignments, attend the class, or actively answer teachers' questions during the learning activities. Second, as a result of this condition, the students' learning achievement is also cannot be best possible. Because of that, Whatsapp Voice Note then is used especially for teaching speaking in order to make students more active in class and in expressing their ideas in English. The learning activities and scenarios are almost the same with the activities in the normal era, just like before the pandemic happens. The difference is that all the instructions, teacher talks and students' talks are delivered through Whatsapp Voice Note.

The data on students' perception of the use of Whatsapp Voice Note in teaching and learning speaking in the pandemic era are obtained through survey and interviews. Students' are asked some questions including (1) How the students' feeling towards the use of Whatsapp Voice Note in the English teaching and learning activities are, (2) Which one that students' preferred between learning through Whatsapp Voice Note or Learning Management System or Youtube or other media, (3) What are the reasons for the answer of question number 2, (4) How the students' feeling when they have to speak and send their assignment by means of Whatsapp Voice Note, and (5) Do the students think that Whatsapp Voice Note is the best suitable media for teaching and learning English especially for speaking skills. 
The result of the survey and interviews show that most of the students feel that using Whatsapp Voice Note for the mobile learning of English speaking skills is able to make the teaching and learning process easier, more fun, and succeed in making students speak up their ideas in English more confidently. The students also think that Whatsapp Voice Note is suitable for teaching and learning of speaking. The reasons why the students prefer Whatsapp Voice Note are because it is easier to be accessed even when they only have limited internet quota and signal. It is sure cannot be happen for other options such as LMS or Youtube since these two options need stronger and bigger internet quota and signal stability. Some of the responses are presented in the table 1 below.

Table 1. Students' Perception

towards the Use of Whatsapp Voice Note in Teaching and Learning of Speaking Skills

\begin{tabular}{|c|c|}
\hline $\begin{array}{l}\text { Respondent } \\
\text { Number }\end{array}$ & Statement \\
\hline Student_1 & $\begin{array}{l}\text { "I prefer Youtube for learning because I can see and listen to the } \\
\text { examples directly. I also can read the written form of some words } \\
\text { so I can also learn how to write correctly. But I think Whatsapp } \\
\text { Voice Note is really suitable for learning speaking. I am happy to } \\
\text { speak English using the Voice Note, even though I still need more } \\
\text { confidence to do so. It is because I am still learning." }\end{array}$ \\
\hline Student_2 & $\begin{array}{l}\text { "I am happy to use Whatsapp Voice Note in learning speaking } \\
\text { because it is easier to understand than Youtube video. In my house, } \\
\text { it is difficult to get a stable internet connection. As a result, I } \\
\text { cannot access Youtube easily. Whatsapp Voice Note is really } \\
\text { appropriate for learning English speaking." }\end{array}$ \\
\hline Student_3 & $\begin{array}{l}\text { "It is fun to learn English using Whatsapp Voice Note. It is because } \\
\text { the explanation using the Voice Note is clearer, especially the } \\
\text { model of pronunciation. It really suits to support the learning of } \\
\text { speaking." }\end{array}$ \\
\hline Student_4 & $\begin{array}{l}\text { "I like using Whatsapp Voice Note in the teaching and learning of } \\
\text { speaking activities. I like it more than Youtube. The explanation is } \\
\text { clearer than that of in Youtube. Actually I am still shy in speaking } \\
\text { English, but the use of the voice note can make me more } \\
\text { confident." }\end{array}$ \\
\hline Student_5 & $\begin{array}{l}\text { "It is fun using Whatsapp Voice Note to learn to speak English. It } \\
\text { is easier to understand and suitable to encourage students to speak } \\
\text { English." }\end{array}$ \\
\hline Student_6 & $\begin{array}{l}\text { "Learning English through Whatsapp Voice Note is good. But I'm } \\
\text { still confused because what I thought I listen in the note differs with } \\
\text { what the word should be written. It makes me unconfident to speak, } \\
\text { I'm afraid if I will make mistakes. Yet I think the Whatsapp Voice } \\
\text { Note is suitable enough for helping me to learn speaking in } \\
\text { English." }\end{array}$ \\
\hline Student_7 & $\begin{array}{l}\text { "Alhamdulillah learning English through Whatsapp Voice Note is } \\
\text { good. But for learning writing, I do not think it is a good idea. I } \\
\text { make many mistakes in writing what I heard in the note. I prefer } \\
\text { Whatsapp Voice Note because it is difficult for me to access } \\
\text { Youtube. I must borrow my sister/brother's mobile phone whenever } \\
\text { I need to access Youtube. I think Whatsapp Voice Note is the best } \\
\text { used for learning how to speak in English." }\end{array}$ \\
\hline Student_8 & $\begin{array}{l}\text { "The explanation is easier to understand when the teacher uses } \\
\text { Whatsapp Voice Note. I feel more ease and fun. I like to learn }\end{array}$ \\
\hline
\end{tabular}




\section{speaking through Whatsapp Voice Note."}

Moreover, the result of observation reveals that most of the students are more active in participating in almost every learning activity. The percentage of students' attendance when the voice note is applied reaches $75 \%$ while the percentages of students' attendance when other media is applied reach only $42 \%$ and $61 \%$. It shows that when the voice note feature is used, the students are eager to join the class. The students also more actively participate in the question-and-answer activity with their friends and the teacher. They also are more courageous in expressing their ideas or speak their mind up in English spoken form. The detailed data are presented in table 2 below.

Table 2. The Percentage of Students' Presence in the English Class

\begin{tabular}{|c|c|c|c|}
\hline No & Date & $\begin{array}{l}\text { Method or Media Used in } \\
\text { Teaching and Learning } \\
\text { Activity }\end{array}$ & $\begin{array}{l}\text { The Percentage of } \\
\text { Students' Presence } \\
\text { in the English Class }\end{array}$ \\
\hline 1 & $\begin{array}{c}\text { Thursday, } 30^{\text {th }} \text { July } \\
2020\end{array}$ & $\begin{array}{l}\text { Learning Management System } \\
\text { (LMS) }\end{array}$ & $\begin{array}{l}39 \text { out of } 64 \text { students } \\
\text { attend the class }(61 \%)\end{array}$ \\
\hline 2 & $\begin{array}{c}\text { Thursday, } 6^{\text {th }} \text { August } \\
2020\end{array}$ & $\begin{array}{l}\text { Learning Management System } \\
\text { (LMS) }\end{array}$ & $\begin{array}{l}27 \text { out of } 64 \text { students } \\
\text { attend the class }(42 \%)\end{array}$ \\
\hline 3 & $\begin{array}{c}\text { Thursday, } 24^{\text {th }} \\
\text { September } 2020\end{array}$ & $\begin{array}{l}\text { Learning Management System } \\
\text { (LMS) }\end{array}$ & $\begin{array}{l}38 \text { out of } 64 \text { students } \\
\text { attend the class }(59 \%)\end{array}$ \\
\hline 4 & $\begin{array}{c}\text { Thursday, } 1^{\text {st }} \text { October } \\
2020\end{array}$ & Whatsapp Voice Note & $\begin{array}{l}48 \text { out of } 64 \text { students } \\
\text { attend the class }(75 \%)\end{array}$ \\
\hline
\end{tabular}

The result of this study is in line with some previous study which investigating the use of Whatsapp Voice Note in the teaching and learning process (Amry, 2014; Gon and Rawekar, 2017; Ayuningtyas, 2018; Riyadoh, 2018; Nurazizah, Frihatin, and Sugiarto, 2019; Yulianto, Cahyani, and Silvianita, 2020). The results of the previous studies show that the use of Whatsapp, especially the Voice Note, is effective in mobile learning of English speaking skill and in improving students' participation in the teaching and learning process.

Furthermore, Whatsapp can be classified as one of the forms of media in Mobile Assisted Language Learning, Mobile-assisted Language Learning, or MALL, is a suitable media especially for learning vocabulary, expressions in English, and for practicing to communicate in English (Kwon and Eun, 2010). MALL is able to function as an efficient media to improve students' learning achievement. Valamarthi (2011) also states that Mobile-assisted Language Learning can be considered as an approach to improve the quality of language learning. Students can access the learning materials and can communicate directly in the target language with their friends and teachers everywhere and anywhere. Some previous studies also shows that foreign language learning using Mobile-assisted Language Learning such as Whatsapp Voijce Note is more effective whether in improving students' learning achievement and/or in improving students' participation, rather than that of the conventional method (Uther, et.al, 2005; Chang, 2005).

However, there are some challenges in using Whatsapp Voice Note for teaching speaking to the seventh grade students. First, some students do not have their own mobile phone. The solution is that they must join others to access the Voice Note. Second, as the main source and model of spoken language, the teachers have to give the best and the most correct example of pronunciation and language form. In other words, the teachers should make sure that what they send to the students through the Whatsapp Voice Note is accurate. Thus, teachers have to improve their speaking skills. 


\section{Conclusions}

The teaching and learning of speaking to the seventh grade students in the pandemic era by means of Whatsapp Voice Note is proven to be able to make the students happier and eager to actively participate in all of the activities. They become more confident to speak up their mind in English and happily attend the class. As a consequence, the teachers have to improve their ability to speak English because they are the main model of the speaking activities.

\section{References}

Amry, A.B. (2014). The Impact of Whatsapp Mobile Social Learning on the Achievement and Attitudes of Female Students Compared with Face-to-face Learning in the Classroom. European Scientific Journal, 10.22, 116-136.

Ayuningtyas, P. (2018). Whatsapp: learning on the go. Metathesis: Journal of English Language Literature and Teaching, 2.2, 159-170.

Brown, H. D. (2000). Teaching by principles: An interactive approach to language pedagogy ( $2^{\text {nd }}$ ed.). New York: Longman.

Chang, M. M. (2005). Applying Self-Regulated Learning Strategies In A Web-Based Instruction: An Investigation of Motivation Perception. Computer Assisted Language Learning, 18, $217-230$.

Gon, S. \& Rawekar, A. (2017). Effectivity of E-Learning through Whatsapp as a Teaching Learning Tool. MVP Journal of Medical Sciences, 4.1, 19-25.

Harmer, J. (2007). The practice of English language teaching (4 $4^{\text {th }}$ ed.). Harlow, England: Longman.

Hartley, J. (2004). A Case Study Research. In Catherine Cassell \& Gillian Symon (Eds.), Essential Guide to Qualitative Methods in Organizational Research (pp.323-333). London: Sage.

Kusuma, W.J., \& Hamidah. (2020). Perbandingan Hasil Belajar Matematika dengan Penggunaan Platform Whatsapp Groupdan Webinar Zoom Dalam Pembelajaran jarak jauh Pada Masa Pandemik Covid 19. JIPMat. http://103.98.176.9/index.php/JIPMat/article/view/5942

Kwon, S., \& Eun, J. (2010). Design Principles of M-Learning for ESL, 2, 1884-1889. doi:10.1016/j.sbspro.2010.03.1003

Mistar, I. (2016). Students' Perception on the Use of WhatsApp as A Leaning Tool in ESL Classroom. Journal of Education and Soial Sciences, 4.

Najafi, H., \& Tridane, A. (2015). Improving Instructor-Student Communication Using Whatsapp: A Pilot Study. 2015 International Conference on Developments of ESystems Engineering (DeSE), 171-175. https://doi.org/10.1109/DeSE.2015.41.

Nurazizah, H., Frihatin, L.Y., \& Sugiarto, B.R. (2019). Whatsapp Voice Note in Speaking Class. Journal of English Education and Teaching, 3.3, 343-360.

Riyadoh, M. (2018). The Effectiveness of Guided Practice Using Voice Message on Whatsapp on Students' Speaking Ability. Sebuah Skripsi, UIN Syarif Hidayatullah, Jakarta.

Uther, M., Zipetria, I., Uther, J., \& Singh, P. (2005). Mobile adaptive CALL (MAC): A Case Study In Developing A Mobile Learning Application For Speech/Audio Language Training. Wireless and Mobile Technologies in Education (IEEE). Tokushima, Japan: IEEE Computer Society.

Valarmathi, K. E. (2011). Mobile Assisted Language Learning. Journal of Technology for ELT. 1(2).

Yulianto, E., Cahyani, P.D., \& Silvianita, S. (2020). Perbandingan Kehadiran Sosial dalam Pembelajaran Daring Menggunakan Whatsapp groupdan Webinar Zoom Berdasarkan Sudut Pandang Pembelajar Pada Masa Pandemic COVID-19. Jurnal Riset Teknologi dan Inovasi Pendidikan (JARTIKA), 3.2, 331-341. 